\title{
FEATURES OF FORMATION OF LOGISTICS SYSTEMS IN FODDER PRODUCTION
}

\author{
Lesya Demydenko, Olha Dyvnych, Oleg Gorb \\ Poltava State Agrarian Academy, Ukraine
}

\begin{abstract}
In the paper theoretical approaches to the definition of «logistics system of fodder production» are presented, its main tasks are highlighted. The author's approach to the formation of logistics system of fodder production is proposed. The principles of logistics systems formation according to a system approach are discussed. The role of information flows in fodder production is substantiated and their characteristics are considered. The paper describes a methodical approach to evaluating the efficiency of the logistics system of fodder production that based on the integral index calculating.
\end{abstract}

Keywords: logistics; fodder production; logistics system; logistics chain; information support; information flow; efficiency

DOI: 10.17512/znpcz.2016.1.10

Market conditions involve the using a logistics approach by a business entity in production, marketing and other commercial activities. This approach allows to outline prospects for a company out of crisis, to choose the right strategy and tactics of effective management, to determine perspective areas for further development. The novelty of the logistics approach is integration of different sectors of activity in order to achieve the desired results with minimal time and resources by means of end-to-end management of material and information flows. The concept of logistics is the system of approaches to rationalization of economic activities by optimizing flow processes.

According to experts, the comprehensive introduction of logistics at enterprises can provide a reduction in stocks by $50 \%$ and $50-70 \%$ - order fulfillment at an enterprise, which manufactures products (Кальченко 2003, p. 87). Studies show that logistics involves «distribution the right product, in the right quantity and right quality, in the right place and at the right time to the right consumer at the right price» (Mangan, Lalwani, Buther 2008, p. 9.).

Modern agricultural production and logistics are developing in accordance with three main trends: consumers of agricultural products orientation, core competencies specialization, the increasing the use of information technology in the agricultural business (Косарева 2003, pp. 23-27; Kalinichenko 2014, pp. 230-237).

The concept of logistics is becoming more widely used. It is defined by managers, decision-makers at the enterprises, as an effective motivational approach to management with the purpose of reducing production costs. This concept becomes the basis for the economic strategy of the company: logistics is used as 
a tool in the competition and considered as managerial logic for plan implementation, allocation and control of financial and human resources. This approach provides close coordination of logistic support and production strategy.

If this coordination is achieved, then the result according to A. Rusalieva's research will be ( Русалева 1996, pp. 22-23):

- right stock lines at the right place and the right time;

- coordination of internal and external transport, that guarantees timely delivery in accordance with the economic requirements;

- synchronicity of operation of storage facilities, packaging and transport, to minimize the cost of raw materials, that enables to reduce its stock at the place of production and stocks of finished products;

- synchronization of orders and transport.

An important task of the effective management of material flows of fodder production is to create a logistics system. There is a high degree of coordination of input resources in end-to-end managing of material flows in the system.

The logistics system of fodder production - a system organization of end-to-end material flow, related information and financial flows, from the purchase of material and technical resources to fodder marketing, to improve the efficiency of the production and marketing of an agricultural enterprise.

In our opinion, the main tasks of the logistics system of fodder production include the following:

- providing the right animal feed;

- complete, timely, integrated and high-quality providing all the resources needed for fodder production and organization of chain management;

- management of transportation, storage and production of feed;

- management of raw materials and finished feed;

- payment management of purchasing of material and technical resources and ready-made feed supply.

S. Grynenko's studies suggest that any logistics system, consisting of a combination of elements, has some functional links and relations. Intra-system communication is stronger than external communication. Usually, they are cyclical because reflect the sequence of transmission of material and information flows between the links of the corresponding supply chain (Гриненко 2004, pp.140-143.).

We believe that the logistics chain of fodder production - a combination of logistics linkages of logistics system of fodder production, through which the movement of material flows, from a supplier of logistical resources (seeds, fertilizers, fuel, etc.) to a consumer of ready-made feeds, passes.

Logistics chain of fodder production consists of the following linkages: purchase of resources, resources storage, fodder production, fodder storage, fodder distribution. Transportation of feeds and resources is an integrating logistics linkage and operation.

In our opinion, the formation of the logistics system of fodder production consists of the following stages (figure 1). 
Firstly, the determination of development strategy for logistics system of fodder production is based on the main objective of logistics system of fodder production and the results of the economic analysis of fodder production. The implementation strategy of the logistics system should not only determine the main objectives of logistics of fodder production, as well as provide logistics system modeling and simulation. It should be noted that the development strategy of the logistics system of fodder production can serve as livestock crisis-proof strategy. The main goal of the logistics system of fodder production is the producing and delivering the right quantity of feeds, right range and assortment, with the right quality at the right time and to the right place with minimal costs.

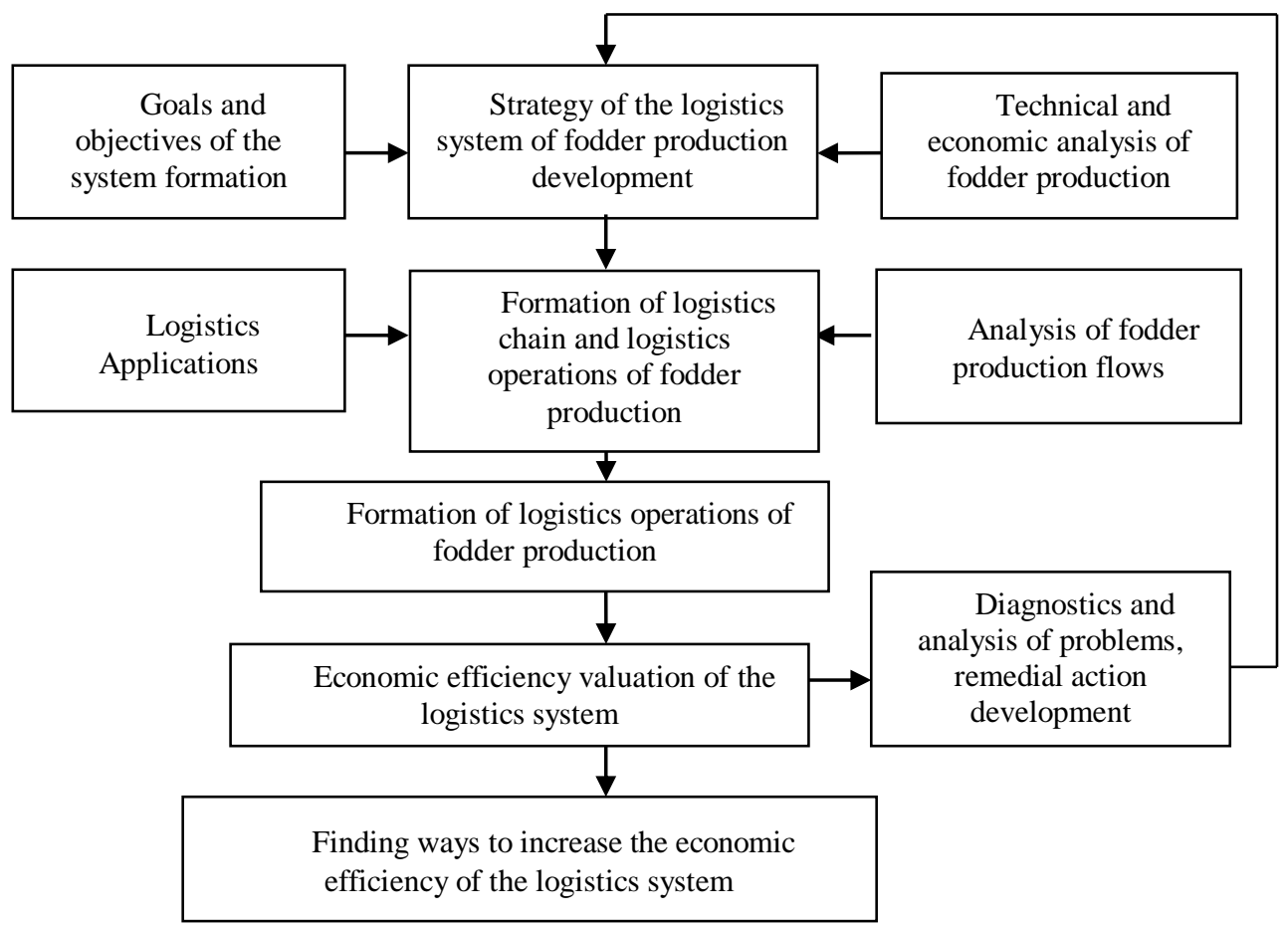

Figure 1. The scheme of formation of logistics operations of fodder production

Source: Author's development.

Secondly, it is the formation of logistics chain of the logistics system of fodder production. For this purpose, you need to determine logistics areas in fodder production and to analyze existing flows. We believe that logistics areas of use are field, meadow and industrial fodder production.

Thirdly, it is the formation of the logistics system as a tool for effective management of material flows within the main stages of fodder production: purchasing, production, warehousing, transportation and distribution.

Fourthly, the evaluation of the efficiency of fodder production of the logistics system is based on the analysis logistics indicators and determination of logistics costs. If the logistics system of fodder production is efficient, then the ways of its 
improvement are suggested. If not, the operational problems are detected, then problem solution is developed and the logistics system of fodder production is formed again.

The functioning of actual logistics systems requires using a system approach. M. Kostin notes that a system approach to logistics - is the direction of the methodology of scientific knowledge that is based on the consideration of objects as systems. Such systems allow investigating the quality and relationships between the objects, which are difficult to study. This means that each system is an integrated overall system even in the case of the combination of various subsystems (Костин 2002, pp. 34-35). At the same time, according to M. Oklander, logistics differs from other theories of the business systems that has the approach to optimization of material flow in general. This approach aims to minimize the integral costs of this material flow (Окландер 2000).

O. Laktionova believes that according to a system approach, the formation of logistics systems at any level of economic system begins with macro-level (economy of a country or group of countries) and ends with micro-level (enterprise) (Лактионова 2002, p. 84.). In addition, the study of I. Sidorov suggests that the following principles of a system approach should be taken into account in the process of designing the logistics systems (Сидоров 1999, p. 49):

- the principle of consistent advancement on the creating system stages;

- the principle of coordination of information, resource and other characteristics of designed systems;

- the principle of no conflict between the goals and objectives of individual subsystems of the entire system.

In the light of the facts mentioned above it is believed that the principles of the formation of the logistics systems of fodder production are:

1) the principle of optimality which stipulates that the main criterion of the logistics system of fodder production functioning is the minimum total logistics costs related to fodder production and marketing;

2) the principle of accounting, which is the analysis of total expenditures within the entire supply chain - from procurement of material and technical resources to ready-made feeds marketing;

3) the principle of consistency that involves the integration of all major linkages of the logistics system of fodder production (purchase of resources, fodder production, feeds and resources transportation, fodder and resources storage, fodder distribution) and their interactions. This principle means the consistency of the material, financial and information flows in order to achieve the objective of fodder production - the producing and delivering the right quantity of feeds, right range and assortment, with the right quality at the right time and to the right place with minimal costs.

4) the principle of sustainability and adaptability of logistics system of fodder production which minimizes the deviation from the norm required quantity of fodder production under the influence of the environment, and adapts to changes in the external and internal environment due to the making appropriate management decisions. 
Logistics deals with the various flows: material flows, financial flows, energy flows, information flows, human flows. The basis of logistics flows in fodder production is material flows.

Taking into account the studies of V. Dorofieiev and V. Lokhmatov about basic requirements for logistics organization of material flows at an enterprise we may note that in fodder production such requirements must provide (Дорофеeв, Лохматов 2002, p. 51):

- rhythmic, coordinated work of all linkages of production according to integrated schedule and the planned output of feeds;

- maximum continuity of production processes (idle-reduction technology);

- maximum reliability of planned payments (careful planning of fodder quantity for existing sex-age groups of animals, based on existing standards) and minimum-plan labor inputs (computerization of production);

- sufficient flexibility in implementation of goals (fodder production of right quality in the right quantity) in the case of various plan deviations;

- continuity of plan management;

- conformity of operational management and processes of fodder production.

The logistics system of fodder production should have sufficient information support, every structural division - experience of its fast and efficient use. This problem is solved at the enterprises by the formation of a complex of automated control systems. It is especially important to improve the information processing system to optimize the levels of material and technical resources, management decision-making, etc. It is necessary to computerize the accounting systems, movement control of material resources in production departments and monitoring the movement of ready-made feeds marketing.

Timely, qualitative information and advanced information technologies form information flows.

We believe that the increasing role of information flow in fodder production is caused by the following reasons:

- for enterprise-consumer the essential element of consumer logistics services is information on the order status, availability of certain type of feeds, delivery terms, shipping documents, and others;

- according to the aspects of inventory management in the logistics chain of fodder production, the availability of complete and accurate information provides the possibility to define the stocks of feeds and raw materials required for the manufacturing;

- information increases the flexibility of the logistics system of fodder production in terms of how, when, and where resources should be used efficiently to achieve the goals of the system.

It is believed that logistics information flows in fodder production have the following features:

1) heterogeneity. Logistics systems information is heterogeneous. It is noteworthy that heterogeneity in linear programming, and in transport problem in fodder production is unlimited ability to transport the feeds from any point to any 
destination. Concerning the movement of information flows within the logistics system of fodder production, requirement of heterogeneity also provides unlimited transmission of any document to managerial apparatus in any structural division;

2) difficulty of practical inspection of the direction of the information flows. The circulating information in logistics system of fodder production can have each time different movement direction depending on which the structural division it must be supplied to in a given period of time;

3 ) the large quantity of information that transmitted during the information flow movement, such as information about the raw material disposition in the company, information about possible suppliers of material and technical resources and availability agreements with them; information about the list of range and assortment of feeds to produce, as well as feeds volumes; information about planned fodder requirement and fodder production terms; information about comparison of actual volumes of fodder production and planned volumes of fodder consumption; information about the volume of consumption of material and technical resources that are required to produce in right quantity and right type of feed, as well as their balance or absence, information about the level prices for material and technical resources;

4) multi-variance of information flows optimization that provides the automation of administrative processes; selection of the complex of computer programs that may meet the present company's hardware and software; the programs ability to ensure all the necessary calculations; the selection of such a program, which would contain a wide range of development tools of basic documents, accounting and financial statements of various standard forms, and forms used in fodder production only for specific enterprise; «hot line» (lines of consultation) of the manufacture for personnel training, assistance to facilitate the program implementation for the enterprise; the price acceptability of the software.

We can define the conditions to be met by the data used to manage the fodder production as:

- ease of interpretation of terms of general economic and livestock categories;

- sufficient information about situation in the industry;

- information accessibility in specific business object (agricultural enterprise, feed factory).

We believe that the basic principles of the organization of information flows in the logistics system of fodder production are:

1) accessibility. It means the simplicity and ease of access to information. Consumers always may receive information on availability of particular type of feeds in store and on process of executing an order;

2) accuracy. Information flows should accurately reflect the current values of logistics indicators (movement of stocks of ready-made feeds and raw materials for the production, the level of these stocks, etc.); 
3) timeliness. Timely information is vital for making the most effective decisions. This means regular updating of information in logistics system, which should reflect all the changes in the logistics system (feeds marketing, quantity of consumed feeds and feeds balance, purchase of raw materials, etc. The use of bar coding, scanning and electronic data interchange will facilitate regular and timely updating of information;

4) flexibility. This principle is aimed to meet the information needs of consumers. Information flows should provide data in accordance with the needs of employees in the supply process or transportation;

5) registration of the reported data. This principle provides displaying and starting the print information in the right format.

We are sure that the effective functioning of information flows is due to open information technologies. Just thanks to the possibility of information exchange in on-line mode the system that integrates material, financial and information flows in single information space is developed.

We believe that the main conditions for the successful functioning of modern information technologies at agricultural enterprises are:

1) computer hardware that enables to process information quickly;

2) computer software that enables each expert to solve their problems with the help of a computer (a chief agronomist - to develop fodder production flow sheets; a chief zootechnician - to formulate livestock feed rations, etc.).

In our opinion, the main factors affecting the efficiency of the logistics systems of fodder production include the average inventory index. The factors that characterize the efficiency of fodder production are feeds quality; production cost of feeds; economic return of feeds (cost of feed in the production cost of 100 UAN (Ukrainian hryvnia), the value of the animal products of 1 UAN of used feeds of animal products, value of obtained animal products of 1 USD costs).

It is obligatory to use such indicator as the level of customer satisfaction, which should reflect the level of feeds supply for livestock in comparison with the needs.

It is determined that integrated indicator of evaluating the efficiency of the logistics system of fodder production $\left(E_{i}\right)$ will have the following form (formulas 1.1-1.5):

$$
\mathrm{E}_{\mathrm{i}}=\mathrm{I}_{\mathrm{lc}} \times \mathrm{I}_{\mathrm{p}} \times \mathrm{I}_{\text {sup }} \times \mathrm{I}_{\mathrm{r}},
$$

where: $I_{l c}$ - index of logistics costs of fodder production;

$I_{p}$ - index of fodder production;

$I_{\text {sup }}$ - feeds supply index;

$I_{r}-$ return index of animal products.

$$
\mathrm{I}_{\mathrm{lc}}=\frac{\mathrm{LC}_{0}}{\mathrm{LC}_{1}},
$$

where: $L C_{1}$ - logistics costs in fodder production over the reporting period, UAH; $L C_{0}-$ logistics costs in fodder production over the base period, UAH. 


$$
\mathrm{Ip}=\frac{\mathrm{VF}_{1}}{\mathrm{VF}_{0}},
$$

where $V F_{l}$ та $V F_{0}$ - volume of produced fodder in accordance with the reporting and base periods, ratio.

$$
\mathrm{I}_{\mathrm{avail}}=\frac{\mathrm{D}_{1} / \mathrm{VF}_{1}}{\mathrm{D}_{0} / \mathrm{VF}_{0}},
$$

where $\mathrm{D}_{l}$ and $\mathrm{D}_{0}$ - demand for feeds in accordance with the reporting and base periods, ratio;

$$
\mathrm{I}_{\mathrm{r}}=\frac{\mathrm{GOAf}_{1}}{\mathrm{GOAf}_{0}},
$$

where GOAfl and GOAfo - cost of gross output of animal husbandry, received cost per unit of supplied feeds in accordance with the reporting and base periods, UAN.

Thus, the logistics system of fodder production will be effective when the integrated indicator of its estimation will be more than 1 . However, it should be noted that in the calculation of the index of logistics costs we should pay attention to the fact, that on the one hand, its growth dynamics suggests the high use of logistics in a company. But on the other hand, the logistics costs of fodder production are a part of the prime costs, so rising logistics costs are a negative phenomenon.

Therefore, the index of logistics costs is calculated by relations between logistics costs of the logistics base period and logistics costs of the reporting period.

Logistics as a factor of improving the efficiency of fodder production is illustrated in figure 2 .

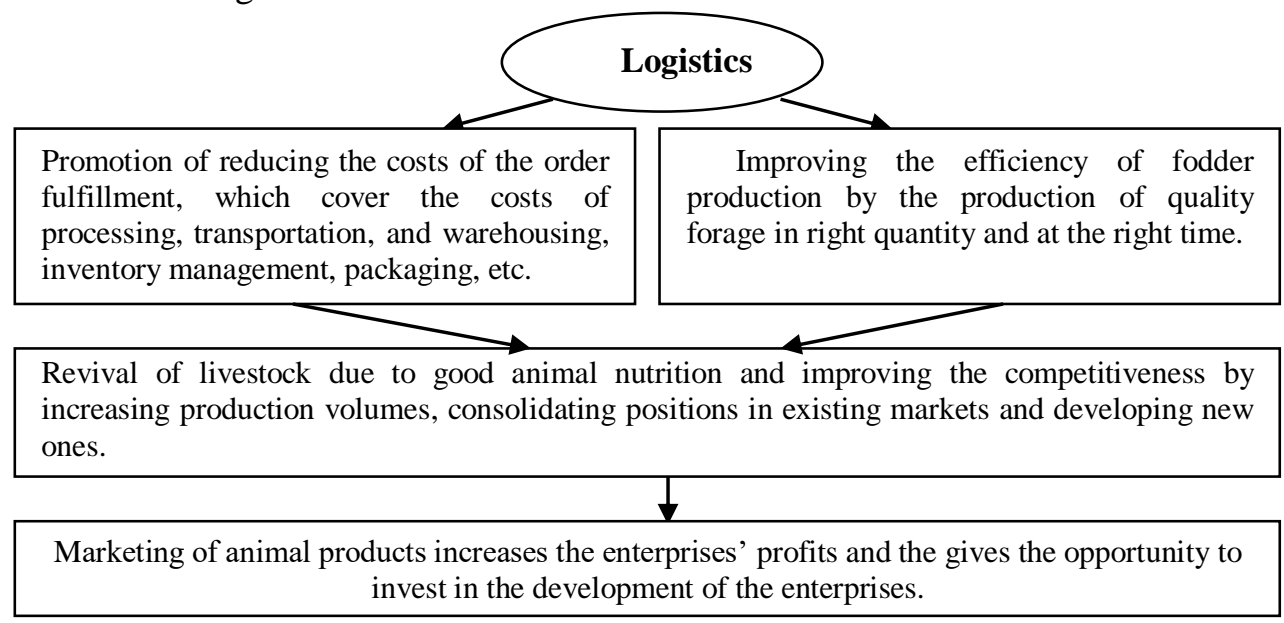

Figure 2. Logistics as a factor of improving the efficiency of fodder production and livestock

Source: Own elaboration. 
Thus, the use of logistics in fodder production provides reducing costs of fodder production; producing the right quantity of feeds, in the right feeds quality and at the right time, focusing on the needs of livestock. This, in turn, makes it possible to improve production efficiency, as feeds will be offered to animals, and to increase the volume of livestock production due to this, thereby covering the requirements of population, consolidating the positions in existing markets and developing new ones.

\section{References}

1. Kalinichenko A.V., The methods of utilization and reuse of excess thermal energy in agricultural production.// Actual Problems of Economics, 2014. - Nr 158 (8), pp. 230-237.

2. Mangan J., Lalwani Ch., Buther T., Global logistics and supply chain management. London: John Wiley \& Sons Ltd, 2008, p. 9.

3. Гриненко С.П., Логістика як інструмент розвитку підприємництва у иукробуряковому під комплексі // Економіка АПК. - 2004. - № 7, pp.140-143.

4. Дорофеев В. Д., Лохматов В.., Логистика: учеб. пособ. - Пенза: ПГУ, 2002, р. 51.

5. Кальченко А. Г., Логістика: підруч.. - К.: КНЕУ, 2003, р. 87.

6. Косарева Т. В., Логістизаиія економіки АПК // Економіка АПК. - 2003. - № 12, pp. $23-27$.

7. Костин М. Ю., Основные принципы формирования логистической системы:: текст лекиій. - Иваново: ИГТА, 2002, pp. 34-35.

8. Лактионова О.Е., Формирование логистических систем: методология и практика ; науч. ред. А. И. Амоша. - Донецк: НАН Украины. Институт экономики промышленности, 2002, p. 84.

9. Окландер М. А., Контуры экономической логистики. - К.: Наукова думка, 2000. - С. 27.

10. Русалева А. Ю., Основы логистики. - Новосибирск, НГАЭУ, 1996, pp. 22-23.

11. Сидоров И. И., Логистическая конщепџия управления промышленным предприятием: учеб. пособ.- СПб.: СПбГИЭА, 1999, р. 49.

\section{CECHY TWORZENIA SYSTEMÓW LOGISTYCZNYCH W PRODUKCJI PASZY}

Streszczenie: W opracowaniu przedstawiono teoretyczne podejścia do definicji „systemu logistycznego produkcji paszy”, wskazując jego główne zadania. Zaproponowano własne podejście do tworzenia systemu logistycznego produkcji paszy. Omówiono zasady tworzenia systemów logistycznych zgodnie z podejściem systemowym. Uzasadniono rolę przepływów informacji w produkcji paszy rozpatrując ich charakterystykę. W opracowaniu przedstawiono podejście metodyczne do oceny skuteczności systemu logistycznego produkcji paszy oparte na rachunku całkowym.

Słowa kluczowe: logistyka, produkcja paszy, system logistyczny, łańcuch logistyczny, wsparcie informacyjne, przepływ informacji, wydajność 